\title{
Pengaruh Konsentrasi Bakteri Asam Laktat Lactobacillus Plantarum Dan Lactobacillus Casei Terhadap Mutu Mikrobiologi Dan Kimia Mayones Probiotik
}

\author{
N. A. Usman ${ }^{1 \mathrm{a}}$, K. Suradi ${ }^{2}$, dan J. Gumilar ${ }^{2}$ \\ ${ }^{I}$ Mahasiswa Program Pascasarjana Fakultas Peternakan Universitas Padjadjaran \\ ${ }^{2}$ Staff Pengajar Fakultas Peternakan Universitas Padjadjaran \\ aemail :nrlazzah@gmail.com
}

\begin{abstract}
Abstrak
Mayones merupakan produk pangan emulsi yang dapat dikembangkan menjadi salah satu pangan fungsional melalui modifikasi dalam proses pengolahannya. Salah satu caranya dengan menambahkan berbagai konsentrasi bakteri asam laktat dalam mayones sehingga bermanfaat bagi kesehatan manusia dan aman untuk dikonsumsi. Bakteri asam laktat yang dapat digunakan adalah Lactobacillus plantarum dan Lactobacillus casei. Tujuan penelitian ini untuk mengetahui pengaruh konsentrasi bakteri asam laktat terbaik terhadap sifat mikrobiologi (jumlah bakteri total dan jumlah bakteri asam laktat) dan sifat kimia ( $\mathrm{pH}$ dan kadar asam laktat) mayones probiotik. Penelitian ini dilakukan secara eksperimental, menggunakan Rancangan Acak Lengkap dengan 6 perlakuan, yaitu $5 \%$ L. plantarum $\left(\mathrm{P}_{1}\right), 5 \%$ L.casei $\left(\mathrm{P}_{2}\right), 10 \%$ L. plantarum $\left(\mathrm{P}_{3}\right), 10 \%$ L.casei $\left(\mathrm{P}_{4}\right), 15 \%$ L. plantarum $\left(\mathrm{P}_{5}\right)$, dan $15 \%$ L.casei $\left(\mathrm{P}_{6}\right)$ dengan 3 kali ulangan. Analisis sidik ragam digunakan untuk mengetahui pengaruh konsentrasi bakteri asam lakat terhadap sifat mikrobiologi dan sifat kimia mayones dan selanjutnya dilanjutkan Uji Tukey untuk mengetahui perbedaan antar perlakuan. Hasil penelitian menunjukkan bahwa konsentrasi $15 \%$ bakteri asam laktat menghasilkan jumlah bakteri total masingmasing sebesar $1,89 \times 10^{9} \mathrm{cfu} / \mathrm{g}$ (L.plantarum), 1,60 × $10^{9} \mathrm{cfu} / \mathrm{g}$ (L.casei) dan jumlah BAL sebesar $2,34 \times 10^{9} \mathrm{cfu} / \mathrm{g}$ (L.plantarum), $2,14 \times 10^{9} \mathrm{cfu} / \mathrm{g}$ (L.casei) tertinggi dengan $\mathrm{pH}$ sebesar 4,42 (L.plantarum), 4,37 (L.casei) dan kadar asam laktat sebesar 0,48\% (L.plantarum), 0,55\% (L.casei).

Kata kunci : bakteri asam laktat, Lactobacillus plantarum, Lactobacillus casei, mayones
\end{abstract}

\section{The Effect Of Concentration Lactic Acid Bacteria Lactobacillus Plantarum And Lactobacillus Casei On Microbiology And Chemestry Properties Of Mayonnaise Probiotic}

\begin{abstract}
Mayonnaise is an emulsion food product that can be developed into one of the functional food thorough modification in the processing process. One of process is by adding various concentration of lactic acid bacteria in the mayonnaise, so that it's beneficial for human health and safe for consumption. Lactic acid bacteria that can be used are Lactobacillus plantarum and Lactobacillus casei. The purpose of this study is to determine the variance concetration lactic acid bacteria and obtain the best various concetration lactic acid bacteria on the microbiology and chemistry properties of mayonnaise probiotic. This study was conducted in experimental used Completely Randomized Design $(C R D)$ with six treatments, $P_{1}\left(5 \%\right.$ L. plantarum), $P_{2}\left(5 \%\right.$ L. casei), $\left(P_{3}\right) 10 \%$ L. plantarum, $P_{4}$ (10\% L. casei), $P_{5}(15 \%$ L. plantarum $)$, and $P_{6}(15 \%$ L. casei) and three replications. Analysis of variance use to determine of various lactic acid bacteria on microbiology and chemistry properties of mayonnaise and then Honestly Significant Difference was used to know the difference between the treatments. Results have shown that the best concetration of $15 \%$ lactic acid bacteria produced the amount total bacteria 1,89 $\times 10^{9} \mathrm{cfu} / \mathrm{g}$ (L. plamtarum), 1,60 $\times 10^{9} \mathrm{cfu} / \mathrm{g}$ (L. casei), and the total lactic acid bacteria 2,34 $\times 10^{9} \mathrm{cfu} / \mathrm{g}$ (L. plamtarum), 2,14 $\times 10^{9} \mathrm{cfu} / \mathrm{g}$ (L. casei), with $\mathrm{pH}$ resulted 4,42 (L. plamtarum), 4,37 (L. casei), and lactic acid levels 0,48\% (L. plamtarum), 0,55\% (L. casei).
\end{abstract}

Keyword: lactic acid bacteria, Lactobacillus plantarum, Lactobacillus casei, mayonnaise 


\section{Pendahuluan}

Permintaan masyarakat akan pangan fungsional dewasa ini semakin meningkat. Pangan fungsional merupakan pangan yang bukan hanya memberikan manfaat nutrisi tetapi juga mempunyai manfaat kesehatan bagi tubuh manusia karena kandungan bahan aktifnya. Telur merupakan bahan pangan bergizi yang diminati masyarakat dan dapat diolah menjadi berbagai macam produk pangan melalui pengolahan baik secara tradisional maupun modern, salah satunya yaitu mayones. Mayones merupakan salah satu produk pangan yang dapat dikembangkan menjadi pangan fungsional melalui modifikasi proses pengolahan sehingga dapat menghasilkan produk pangan yang memiliki nilai manfaat kesehatan bagi tubuh.

Mayones merupakan produk olahan telur berbasis emulsi semi solid minyak dalam air. Produk pangan berbasis emulsi ini sudah mulai disukai oleh kalangan masyarakat. Biasanya mayones dikonsumsi sebagai olesan atau pelengkap dalam suatu hidangan makanan. Mayones terbuat dari pencampuran minyak secara perlahan dengan kuning telur sebagai emulsifier dan bahan lainnya, seperti larutan cuka, mustard, gula, dan garam. Salah satu modifikasi pengolahan mayones dengan penambahan bakteri asam laktat yang bermanfaat bagi kesehatan manusia dan aman dikonsumsi.

Bakteri asam laktat (BAL) merupakan salah satu jenis bakteri yang mampu memproduksi senyawa metabolit sebagai antibakteri. Bakteri asam laktat berperan dalam proses fermentasi makanan maupun minuman. Produk fermentasi memiliki nilai gizi lebih tinggi dibandingkan dengan bahan asalnya, karena mikroba yang terdapat pada produk fermentasi dapat memecah komponen kompleks menjadi bahan yang lebih sederhana sehingga mudah dicerna. Starter yang sering digunakan pada produk fermentasi merupakan bakteri asam laktat yang memiliki kemampuan bertahan hidup dalam saluran pencernaan serta dapat menekan pertumbuhan bakteri perusak dan patogen. Peran utama bakteri ini adalah untuk mengawetkan bahan makanan dengan menghasilkan asam laktat, asam asetat, etanol, $\mathrm{CO}_{2}$, serta bakteriosin (Desmazeaud, 1996). Bakteriosin merupakan senyawa antimikroba yang diproduksi oleh bakteri asam laktat yang dapat digunakan sebagai pengawet alam dalam menghambat bakteri patogen yang berbahaya (Savadogo, et. al., 2006).

Lactobacilus plantarum dan Lactobacillus casei merupakan bakteri asam laktat yang berpotensi sebagai biopresevatif karena mampu menghambat pertumbuhan bakteri patogen dan perusak. Lactobacillus plantarum memiliki kemampuan menghambat pertumbuhan bakteri patogen dengan daya hambat terbesar dibandingkan dengan bakteri asam laktat lainnya. Senyawa antimikroba yang dihasilkan dari Lactobacillus plantarum yaitu plantaricin (Fardiaz, 1992). Selain itu, Lactobacillus casei juga menghasilkan asam laktat yang diperoleh dari fermentasi glukosa dan pembentukan laktat yang bersifat homofermentatif dengan membentuk laktat murni hampir 85\% (Farinde, et. al., 2010).

Adanya penambahan bakteri asam laktat pada produk pangan akan menurunkan $\mathrm{pH}$ substrat sehingga bakteri perusak dan patogen akan terhambat pertumbuhannya, sehingga tidak menutup kemungkinan bahwa penambahan bakteri tersebut dengan berbagai konsentrasi pada mayones akan memberikan daya awet yang baik. Oleh karena itu, berdasarkan uraian yang telah dijelaskan, Penulis tertarik melakukan penelitian mengenai pengaruh konsentrasi bakteri asam laktat Lactobacillus plantarum dan Lactobacillus casei terhadap mutu mikrobiologi dan kimia mayones probiotik.

\section{Materi dan Metode \\ Bahan dan Alat}

Bakteri asam laktat yang akan ditambahkan dalam mayones adalah isolat ALG B. 113 Lactobacillus plantarum dan ALG B.212 Lactobacillus casei. Bahan yang digunakan dalam pembuatan mayones, adalah kuning telur, minyak zaitun, gula, garam, larutan cuka 5\%, mustard, dan skim. Sedangkan bahan kimia yang digunakan, adalah aquades, MRSA (Man Ragosa Sharpe Agar), NA (Nutrient Agar), $\mathrm{NaCl}$ fisiologis, $\mathrm{NaOH} 0,1 \mathrm{~N}$, dan phenolptalein. Alat yang digunakan adalah buret, erlemeyer, hand mixer, inkubator, petridish disposable, $\mathrm{pH}$ meter, dan timbangan analitik

\section{Pembuatan Mayones}

Kuning telur, gula, garam, skim, dan mustard dimasukkan ke dalam mangkok bulat kemudian dikocok menggunakan handmixer 
hingga homogen. Larutan cuka ditambahkan dalam jumlah tertentu, selanjutnya minyak zaitun ditambahkan secara bertahap sambil dikocok. Setelah adonan homogen, mayones ditambahkan bakteri asam laktat sebanyak $5 \%$, $10 \%$, dan $15 \%$, kemudian inkubasi selama 48 jam dalam suhu $37^{\circ} \mathrm{C}$, sehingga diperoleh mayones probiotik.

\section{Jumlah Bakteri Total}

Jumlah bakteri dihitung dengan metode Total Plate Count setiap perlakuan dengan pengenceran hingga $10^{-7}$. Sampel disiapkan secara aseptik, dengan menimbang sampel sebanyak 25 g dimasukkan ke dalam tabung erlenmeyer berisi $225 \mathrm{ml}$ BPW (pengenceran $10^{-1}$ ), melakukan pengenceran dengan memindahkan $1 \mathrm{ml}$ suspensi pengenceran $10^{-1} \mathrm{ke}$ dalam tabung reaksi yang berisi $9 \mathrm{ml}$ larutan BPW, kemudian dilakukan pengenceran hingga $10^{-7}$. Masing-masing $1 \mathrm{ml}$ dari tingkat pengenceran $10^{-6}$ dan $10^{-7}$ dimasukkan ke dalam cawan petri steril dan tuangkan 15-20 ml PCA, homogenkan dengan menggoyangkan petri dengan hati-hati hingga tercampur merata dan memadat. Inkubasi pada suhu $34-36^{\circ} \mathrm{C}$ selama $24-48$ jam dengan posisi cawan terbalik (SNI 01-2897:2008). Perhitungan jumlah bakteri dilakukan berdasarkan Bacteriological Analytical Manual (Maturin dan Peeler, 2001), dengan rumus perhitungan sebagai berikut :

$$
N=\frac{\sum C}{\left[\left(1 \times n_{1}\right)+\left(0,1 \times n_{2}\right) \times(d)\right]}
$$

Keterangan :

$\mathrm{N} \quad$ : Jumlah koloni per ml produk

$\sum \mathrm{c}$ : Jumlah total koloni pada semua plate $(25-250)$

n1 : Jumlah plate yang dapat dihitung pada pengenceran pertama

n2 : Jumlah plate yang dapat dihitung pada pengenceran kedua

d : Pengenceran pertama yang dihitung/ memenuhi ketentuan (25250)

\section{Total Bakteri Asam Laktat}

Pengujian bakteri asam laktat diawali dengan menimbang sampel $50 \mathrm{mg}$ dimasukkan ke dalam Erlenmeyer berisi $450 \mathrm{ml}$ larutan pelarut (pengenceran $10^{-1}$ ). Dilakukan pengenceran dengan memindahkan $1 \mathrm{ml}$ suspensi pengenceran $10^{-1} \mathrm{ke}$ dalam tabung reaksi yang berisi $9 \mathrm{ml}$ larutan pelarut, kemudian dilakukan pengenceran hingga $10^{-7}$. Masing-masing $1 \mathrm{ml}$ dari tingkat pengenceran $10^{-6}$ dan $10^{-7}$ dimasukkan ke dalam cawan petri steril. Media MRSA 12-15 ml dituangkan pada masing-masing cawan petri, digoyangkan hingga sampel dan media tercampur merata dan memadat. Inkubasi pada $35^{\circ} \mathrm{C}$ selama 3 hari (SNI 2981:2009). Perhitungan koloni dilakukan dengan rumus perhitungan sebagai berikut :

$$
\begin{gathered}
\text { Jumlah bakteri starter }(\text { koloni } / g) \\
=n \times F
\end{gathered}
$$

Keterangan :

$\mathrm{n}$ : Rata-rata koloni dari dua cawan dari satu pengenceran

F : Faktor pengenceran dari rata-rata koloni yang dipakai

\section{pH}

Pengukuran $\mathrm{pH}$ dilakukan dengan menggunakan $\mathrm{pH}$ meter. Alat $\mathrm{pH}$ meter dikalibrasi terlebih dahulu dengan buffer untuk $\mathrm{pH} 4$ dan $\mathrm{pH}$ 7. Pengukuran dilakukan dengan mencelupkan elektroda $\mathrm{pH}$ meter ke dalam 10 ml sampel (AOAC, 1995).

\section{Kadar Asam Laktat}

Pengujian kadar asam laktat dilakukan dengan cara, sebagai berikut menimbang 20 gram sampel mayones kemudian dimasukkan ke dalam erlenmeyer, lalu dilarutkan dalam air bebas $\mathrm{CO}_{2}$ sebanyak 2 kali volume sampel. Kemudian ditambahkan $2 \mathrm{ml}$ indikator phenolphetalein dan titrasi dengan larutan $\mathrm{NaOH} 0,1 \mathrm{~N}$ sampai terbentuk warna merah muda. Kadar asam laktat dihitung dengan rumus :

$$
\text { Jumlah asam }(\%)=\frac{\mathrm{V} \times \mathrm{N} \times 90}{\mathrm{~W}} \times 100 \%
$$

Keterangan :

$$
\begin{array}{ll}
\mathrm{W} & \text { : bobot sampel, }(\mathrm{mg}) \\
\mathrm{V} & \text { : volume larutan } \mathrm{NaOH},(\mathrm{ml}) \\
\mathrm{N} & \text { : normalitas larutan } \mathrm{NaOH} ; \\
90 & \text { : bobot setara asam laktat. }
\end{array}
$$

\section{Analisis Statistika}

\begin{tabular}{lcr}
\multicolumn{2}{c}{ Penelitian dilakukan } & secara \\
eksperimental di laboratorium & dengan \\
menggunakan Rancangan Acak Lengkap
\end{tabular} (RAL) dengan 6 perlakuan dan setiap perlakuan dilakukan pengulangan sebanyak 3 kali. Perlakuan dilakukan dengan 6 jenis konsentrasi penambahan bakteri asam laktat $L$. 
plantarum dan L.casei. selanjutnya untuk mengetahuin tingkat perbedaan setiap perlakuan berbagai konsentrasi penambahan bakteri asam laktat diuji menggunakan Uji Tukey.

\section{Hasil dan Pembahasan}

\section{Sifat Mikrobiologi Mayones}

Pengaruh perlakuan terhadap jumlah bakteri total dan total bakteri asam laktat mayones tercantum pada Tabel 1 .

Penambahan berbagai konsentrasi bakteri asam laktat terhadap jumlah bakteri total menghasilkan jumlah terbesar pada penambahan sebanyak $15 \% \mathrm{P}_{5}$ (L. plantarum) sebesar $1,89 \times 10^{9} \mathrm{cfu} / \mathrm{g}$ dan $\mathrm{P}_{6}$ (L. casei) sebesar $1,60 \times 10^{9} \mathrm{cfu} / \mathrm{g}$, akan tetapi pada penambahan bakteri asam laktat sebesar 5\% $\left(\mathrm{P}_{1}\right.$ dan $\left.\mathrm{P}_{2}\right)$ bakteri asam laktat maupun bakteri lain tidak tumbuh. Hal ini menunjukkan bahwa aktivitas mikroba $L$. plantarum dan $L$. casei pada konsentrasi 5\% tidak berkembang secara optimal dikarenakan populasinya yang kurang memungkinkan tumbuh dalam media mayones. Namun pada penambahan sebanyak $10 \%$ dan $15 \%$ memungkinkan populasi yang dibutuhkan cukup untuk berkembang dalam media mayones.

Berdasarkan Tabel 1, menunjukkan bahwa jumlah bakteri total pada perlakuan penambahan $15 \%$ L. plantarum $\left(\mathrm{P}_{5}\right)$ tertinggi sebesar $1,89 \times 10^{9} \mathrm{cfu} / \mathrm{g}$ berbeda nyata $(\mathrm{P}<0,05)$ dibandingkan dengan perlakuan $5 \%$ L. plantarum $\left(\mathrm{P}_{1}\right), 5 \%$ L. casei $\left(\mathrm{P}_{2}\right), 10 \%$ L. plantarum $\left(\mathrm{P}_{3}\right), 10 \%$ L.casei $\left(\mathrm{P}_{4}\right)$, dan $15 \%$ L.casei $\left(\mathrm{P}_{6}\right)$. Begitu juga dengan perlakuan $\mathrm{P}_{2}$ $\left(1,60 \times 10^{9} \mathrm{cfu} / \mathrm{g}\right)$ berbeda nyata $(\mathrm{P}<0,05)$ dengan perlakuan $\mathrm{P}_{1}, \mathrm{P}_{2}, \mathrm{P}_{3}, \mathrm{P}_{4}$, dan $\mathrm{P}_{6}$, namun pada perlakuan $\mathrm{P}_{1}$ dengan $\mathrm{P}_{2}$ dan $\mathrm{P}_{3}$ dengan $\mathrm{P}_{4}$ masing-masing satu sama lain tidak berbeda nyata.

Data pada Tabel 1. menunjukkan bahwa terjadi peningkatan jumlah bakteri total seiring bertambahnya konsentrasi bakteri asam laktat yang ditambahkan. Hal ini menunjukkan bahwa terjadi aktivitas mikroba L. plantarum dan L.casei selama proses fermentasi. Menurut Badan Standarisasi Nasional (1998), syarat mutu mayones sesuai dengan SNI-01-4473-1998 menunjukkan bahwa mikroba mayones memiliki angka lempeng total yaitu maksimal $10^{4} \mathrm{koloni} / \mathrm{g}$. Akan tetapi, dalam penambahan berbagai konsentrasi bakteri asam laktat terjadi peningkatan hingga $10^{9}$ pada penambahan bakteri asam laktat pada konsentrasi. Hal ini menunjukkan bahwa bakteri yang terhitung merupakan bakteri asam laktat yang tumbuh dari penambahan berbagai konsentrasi bakteri asam laktat.

Penambahan berbagai konsentrasi bakteri asam laktat terhadap jumlah bakteri asam laktat menghasilkan jumlah terbesar pada penambahan sebanyak $15 \% \quad \mathrm{P}_{5} \quad(L$. plantarum) sebesar $2,34 \times 10^{9} \mathrm{cfu} / \mathrm{g}$ dan $\mathrm{P}_{6}(L$. casei) sebesar $2,17 \times 10^{9} \mathrm{cfu} / \mathrm{g}$, akan tetapi pada penambahan bakteri asam laktat sebesar 5\% $\left(\mathrm{P}_{1}\right.$ dan $\left.\mathrm{P}_{2}\right)$ bakteri asam laktat tidak tumbuh. Hal ini menunjukkan bahwa aktivitas mikroba $L$. plantarum dan $L$. casei tidak berkembang secara optimal pada penambahan $5 \%$ bakteri asam laktat karena populasinya yang kurang untuk berkembang dalam mayones.

Tabel 1. Pengaruh Perlakuan terhadap Jumlah Bakteri Total dan Total Bakteri Asam Laktat Mayones Probiotik

\begin{tabular}{|c|c|c|c|c|c|c|}
\hline \multirow{2}{*}{ Peubah yang Diamati } & \multicolumn{6}{|c|}{ Perlakuan } \\
\hline & $\mathbf{P}_{1}$ & $\mathbf{P}_{2}$ & $\mathbf{P}_{3}$ & $\mathbf{P}_{4}$ & $\mathbf{P}_{5}$ & $\mathbf{P}_{6}$ \\
\hline \multicolumn{7}{|c|}{ 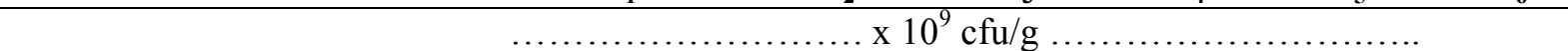 } \\
\hline Jumlah Bakteri Total & $0^{\mathrm{d}}$ & $0^{\mathrm{d}}$ & $1,12^{\mathrm{c}}$ & $1,17^{\mathrm{c}}$ & $1,89^{\mathrm{a}}$ & $1,60^{\mathrm{b}}$ \\
\hline Jumlah BAL & $0^{\mathrm{c}}$ & $0^{\mathrm{c}}$ & $1,15^{\mathrm{b}}$ & $2,03^{a b}$ & $2,34^{\mathrm{a}}$ & $2,17^{\mathrm{a}}$ \\
\hline \multicolumn{7}{|c|}{$\begin{array}{cl}\text { Keterangan } & \begin{array}{l}\text { Nilai yang diikuti huruf kecil yang berbeda kearah baris pada kolom yang sama menunjukkar } \\
\text { berbeda nyata }\end{array}\end{array}$} \\
\hline \multicolumn{7}{|c|}{$\mathrm{P}_{1}:$ Mayones dengan 5\% Lactobacillus plantarum } \\
\hline \multicolumn{7}{|c|}{$\mathrm{P}_{2}$ : Mayones dengan 5\% Lactobacillus casei } \\
\hline \multicolumn{7}{|c|}{$\mathrm{P}_{3}$ : Mayones dengan $10 \%$ Lactobacillus plantarum } \\
\hline \multicolumn{7}{|c|}{$\mathrm{P}_{4}:$ Mayones dengan $10 \%$ Lactobacillus casei } \\
\hline \multicolumn{7}{|c|}{$\mathrm{P}_{5}$ : Mayones dengan $15 \%$ Lactobacillus plantarum } \\
\hline \multicolumn{7}{|c|}{$\mathrm{P}_{6}:$ Mayones dengan $15 \%$ Lactobacillus casei } \\
\hline
\end{tabular}


Berdasarkan Tabel 1, jumlah bakteri asam laktat pada perlakuan penambahan sebanyak $15 \%$ L. plantarum $\left(\mathrm{P}_{5}\right)$ tertinggi sebesar $2,34 \times 10^{9} \mathrm{cfu} / \mathrm{g}$ berbeda nyata $(\mathrm{P}<0,05)$ dibandingkan dengan perlakuan $5 \%$ L. plantarum $\left(\mathrm{P}_{1}\right), 5 \%$ L. casei $\left(\mathrm{P}_{2}\right), 10 \% L$. plantarum $\left(\mathrm{P}_{3}\right)$ dan $10 \%$ L.casei $\left(\mathrm{P}_{4}\right)$. Demikian dengan perlakuan $\mathrm{P}_{1}$ dengan $\mathrm{P}_{2}$ dan $\mathrm{P}_{5}$ dengan $\mathrm{P}_{6}$ satu sama lain tidak berbeda nyata. Namun perlakuan $\mathrm{P}_{3}$ dengan $\mathrm{P}_{4}$ berbeda nyata satu sama lain. Hal ini menunjukkan bahwa penggunaan bakteri L.casei $\left(\mathrm{P}_{4}\right)$ memiliki aktivitas yang lebih baik dibandingkan dengan L. plantarum $\left(\mathrm{P}_{3}\right)$.

Mengacu pada target probiotik pada produk pangan mengandung bakteri asam laktat sebanyak $1 \times 10^{7} \mathrm{CFU} / \mathrm{g}$ pada akhir masa simpan untuk memastikan efek probiotik dapat bertahan hidup pada saluran pencernaan target (Quinto, et. al., 2007). Menurut Sriwidowoti (2003) jumlah mikroba dalam produk laktat agar dapat memberikan manfaat kesehatan adalah berjumlah $10^{7}-10^{10}$ koloni/ml sehingga dapat bersaing dengan mikroba patogen. Berdasarkan data tersebut, dapat dikatakan bahwa mayones dengan penambahan $10 \%$ dan $15 \%$ bakteri asam laktat telah memenuhi standar.

Nilai total bakteri asam laktat mayones mengalami peningkatan seiring dengan bertambahnya konsentrasi penambahan bakteri asam laktat yang ditambahkan. Konsentrasi penambahan bakteri asam laktat memberikan nilai signifikan, semakin banyak bakteri asam laktat akan mempercepat proses glikolisis pemecahan glukosa menghasilkan asam laktat. Meningkatnya total bakteri asam laktat di dalam produk fermentasi dapat dipengaruhi oleh kandungan nutrisi dalam mayones, sehingga pertumbuhan bakteri asam laktat optimal.

Perubahan jumlah total bakteri asam laktat terjadi selama fermentasi. Pada proses fermentasi, laktosa diubah oleh bakteri asam laktat menjadi asam laktat. Meningkatnya total bakteri asam laktat dipengaruhi oleh nutrisi dalam mayones. Kumalasari dkk. (2012) menyatakan bahwa sel sel bakteri asam laktat mampu tumbuh dan membelah diri secara aksponensial sampai jumlah maksimum yang dipengaruhi oleh kondisi lingkungan dan nutrisi di dalam media. Pertumbuhan mikroba dalam bahan pangan erat kaitannya dengan media tumbuh yang tersedia untuk pertumbuhan mikroba di dalamnya.

Semakin banyak jumlah bakteri asam laktat yang diberikan dalam produk makan akan menyebabkan semakin banyak jumlah bakteri $L$. plantarum dan $L$. casei yang dapat menghidrolisis karbohidrat menjadi asam laktat. Dilihat dari data bahwa jumlah bakteri asam laktat meningkat seiiring dengan meningkatnya penambahan bakteri asam laktat hingga $15 \%$. Hal ini sejalan dengan pendapat Afrizal (1989) yang menyatakan bahwa semakin tinggi tingkat konsentrasi penambahan bakteri asam laktat yang ditambahkan, maka akan meningkatkan total bakteri asam laktat yang dihasilkan. Selain itu juga, diduga bahwa lama fermentasi yang dilakukan selama 24 jam tersebut dapat dimanfaatkan secara optimal oleh bakteri asam laktat untuk pertumbuhannya dengan mendapatkan suplai energi dari hasil perombakan karbohidrat, glukosa, dan laktosa dalam susu skim yang ditambahkan dalam pembuatan mayones.

Konsentrasi penambahan bakteri asam laktat pada mayones menghasilkan kadar asam laktat masing-masing sebesar $\mathrm{P}_{1} 0,26 ; \mathrm{P}_{2} 0,32$; $\mathrm{P}_{3} 0,39 ; \mathrm{P}_{4} 0,44 ; \mathrm{P}_{5} 0,48$; dan $\mathrm{P}_{6} 0,55$ (Tabel 2). Data pada Tabel 2, menunjukkan terjadinya peningkatan kadar asam laktat dengan bertambahnya konsentrasi penambahan bakteri asam laktat karena aktivitas mikroba Lactobacillus plantarum dan Lactobacillus casei meningkat dan jumlah mikroba semakin banyak, sehingga menyebabkan jumlah asam laktat yang terbentuk semakin banyak.

\section{Sifat Kimia Mayones}

Pengaruh perlakuan terhadap $\mathrm{pH}$ dan kadar asam laktat mayones tercantum pada Tabel 2. 
Tabel 2. Pengaruh Perlakuan terhadap pH dan Kadar Asam Laktat Mayones Probiotik

\begin{tabular}{|c|c|c|c|c|c|c|}
\hline \multirow{2}{*}{ Peubah yang Diamati } & \multicolumn{6}{|c|}{ Perlakuan } \\
\hline & $\mathbf{P}_{1}$ & $\mathbf{P}_{2}$ & $\mathbf{P}_{3}$ & $\mathbf{P}_{4}$ & $\mathbf{P}_{5}$ & $P_{6}$ \\
\hline $\mathrm{pH}$ & $5,18^{\mathrm{a}}$ & $5,11^{\mathrm{a}}$ & $4,58^{b}$ & $4,57^{b}$ & $4,42^{\mathrm{c}}$ & $4,37^{\mathrm{c}}$ \\
\hline Kadar Asam Laktat (\%) & $0,26^{\mathrm{ac}}$ & $0,32^{\mathrm{ac}}$ & $0,39^{\mathrm{ab}}$ & $0,44^{\mathrm{ab}}$ & $0,48^{\mathrm{a}}$ & $0,55^{\mathrm{a}}$ \\
\hline
\end{tabular}

Total asam laktat merupakan pengukuran semua komponen asam, baik yang terdisosiasi, disamping asam laktat terkandung juga asam-asam lain yang mudah terdisosiasi, seperti asam asetat, dan asam format (Hernawati, 2002). Semakin banyak asam laktat yang terbentuk maka nilai $\mathrm{pH}$ akan semakin menurun. Hal ini sesuai dengan pendapat Nizori, dkk. (2007) bahwa nilai keasaman dan $\mathrm{pH}$ memiliki hubungan erat dengan meningkatnya aktivitas metabolisme sehingga produksi asam laktat semakin meningkat sedangkan nilai $\mathrm{pH}$ menurun. Selain itu Winanrno dan Fernandez (2007) menjelaskan bahwa asam laktat yang dihasilkan selama proses fermentasi dapat meningkatkan citarasa dan meningkatkaan keasaman atau menurunkan pHnya.

Pada perlakuan konsentrasi
penambahan bakteri asam laktat $5 \%$ jumlah asam laktat yang tidak terlalu tinggi, namun peningkatan asam laktat yang cukup tinggi pada perlakuan konsentrasi penambahan $10 \%$ (P3 dan P4) dan penambahan 15\% (P5 dan P6). Hal ini diduga karena penambahan bakteri asam laktat masih relatif sedikit. Semakin tinggi konsentrasi bakteri asam laktat yang ditambahkan, makan akan semakin tinggi jumlah bakteri asam laktat yang dapat menghidrolisis karbohidrat menjadi asam laktat dan dapat meningkatkna kemampuan bakteri untuk memecah laktosa dalam susu skim yang ditambahkan dalam mayones.

Penambahan berbagai konsentrasi bakteri asam laktat menghasilkan rata-rata $\mathrm{pH}$ mayones masing-masing sebesar $\mathrm{P}_{1} 5,18 ; \mathrm{P}_{2}$ 5,$11 ; \mathrm{P}_{3} 4,58 ; \mathrm{P}_{4} 4,57 ; \mathrm{P}_{5} 4,42 ;$ dan $\mathrm{P}_{6} 4,37$ (Tabel 2). Data pada Tabel 2, menunjukkan bahwa $\mathrm{pH}$ mayones pada perlakuan penambahan bakteri asam laktat 15\% $\left(\mathrm{P}_{5}, \mathrm{P}_{6}\right)$ berbeda nyata $(\mathrm{P}<0,05)$ dibandingkan dengan perlakuan penambahan bakteri asam laktat $5 \%$ (P1, P2) dan $10 \%$ (P3, P4). Hal ini menunjukkan bahwa $\mathrm{pH}$ mayones menurun seiring dengan meningkatnya konsentrasi penambahan bakteri asam laktat. Dengan bertambahnya konsentrasi bakteri asam laktat, aktivitas mikroba Lactobacillus plantarum dan Lactobacillus casei meningkat dan jumlah mikroba semakin banyak, sehingga menyebabkan kadar asam laktat yang terbentuk semakin banyak dan $\mathrm{pH}$ mayones akan menurun.

Penurunan $\mathrm{pH}$ merupakan salah satu akibat dari proses fermentasi yang terjadi karena adanya akumulasi asam laktat dan asam organik. Menurut Fardiaz (1992), glukosa dirombak oleh bakteri asam laktat menjadi asam laktat, asam piruvat, asam asetat, etanol, dan $\mathrm{CO}_{2}$ sehingga meningkatkan total asam dan menurunkan $\mathrm{pH}$. Hal ini sejalan dengan pendapat Charalampopoulus, et.al., (2000) yang menyatakan bahwa akumulasi asam laktat yang dihasilkan dari metabolism bakteri asam laktat dapat menurunkan $\mathrm{pH}$ medium. Kondisi ini akan menghambat pertumbuhan bakteri patogen (Obermen dan Libudszis, 1998).

\section{Kesimpulan}

Berdasarkan hasil analisis disimpulkan bahwa penambahan konsentrasi bakteri asam laktat memberika pengaruh berbeda terhadap sifat mikrobiologi (jumlah bakteri asam laktat dan jumlah bakteri total) dan sifat kimia ( $\mathrm{pH}$ dan kadar asam laktat) mayones probiotik. Penggunaan konsentrasi bakteri asam laktat sebanyak 15\% menghasilkan mayones dengan sifat mikrobiologi tertinggi dengan menghasilkan jumlah bakteri total masingmasing sebesar $1,89 \times 10^{9} \mathrm{cfu} / \mathrm{g}$ (L.plantarum), $1,60 \times 10^{9} \mathrm{cfu} / \mathrm{g}$ (L.casei) dan jumlah BAL sebesar 2,34 x $10^{9} \mathrm{cfu} / \mathrm{g}$ (L.plantarum), 2,14 x $10^{9} \mathrm{cfu} / \mathrm{g}$ (L.casei), serta sifat kimia yang terbaik dengan $\mathrm{pH}$ sebesar 4,42 (L.plantarum), 4,37 (L.casei) dan kadar asam laktat sebesar $0,48 \%$ (L.plantarum), 0,55\% (L.casei).

\section{Ucapan Terimakasih}

Penulis berterimakasih kepada semua pihak yang telah membantu dalam berlangsungnya 
penelitian ini sehingga selesai sesuai dengan yang diharapkan yaitu Laboratorium Riset dan Pengujian Bioteknologi Fakultas Peternakan Universitas Padjadjaran dan Academic Leadership Grant (ALG) yang telah mendanai penelitian ini.

\section{Daftar Pustaka}

Afrizal, M. 1989. Study Tingkat Penambahan Starter dan Lama Inkubasi terhadap Mutu Yoghurt. Tesis Teknologi Hasil Pertanian. Fakultas Pertanian. Universitas Lampung. Bandar Lampung.

AOAC. 2000. Official Methods of Analysis $\left(17^{\text {th }}\right.$ ed). Gaithersburg, MD. USA. Association of Official Analytical Chemists.

Badan Standar Nasional. 2009. Yoghurt. Jakarta. (SNI 2981 : 2009). 2008. Metode Pengujian Cemaran Mikroba dalam Daging, Telur, dan Susu, serta Hasil Olahannya. Jakarta. (SNI 2897 : 2008).

01-4473-1998) 1998. Mutu Mayones. Jakarta. (SNI

Charalampopoulos, D, R. Wang, S.S. Pandiella, C. Webb. 2002. Application of Cereals and Cereals Component in Functional Food : Review. International Journal of Food Microbiology (79). Hal : 131-141.

Desmazeaud, M. 1996. Lactic Acid Bacteria in Food : Use and Safety. Cahiers Agricultures 5(5): 331-342.

Fardiaz, S. 1992. Mikrobiologi Pangan I. Jakarta : Bumi Aksara.

Farinde, E.O., V.A. Oba Tom, M.A. Oyarekhua, and O.T. Olanipekun. 2010. Physical and Microbial Properties of Fruit Flavored Fermented Cow Milk and Soymilk (Yoghurt-Like) Under Different Temperature of Storage. African J. Food Sci. and Technol. I(5):120-127.

Kumalasari, K.E.D, Nurwantoro, dan S. Mulyani., 2012, Pengaruh Kombinasi Susu dengan Air Kelapa Terhadap Total Bakteri Asam Laktat (BAL), Total Gula, dan Keasaman Drink Yoghurt. Jurnal Aplikasi Teknologi Pangan, 1 (2): 48-53.

Maturin, L. dan J.T Peeler. 2001. Aerobic Plate Count. Di dalam Bacteriological Analytical Manual Online. Center for
Food Safety and Applied Nutrition. USA:

U.S. Food and Drug Administration.

Obermen dan Libudszis. 1998. Fermented Milk. Elsevier Applied Science Pub. New York.

Quinto, E., P. Jiménez, I. Caro, J. Tejero, J. Mateo and T. Girbés. 2014 Probiotic Lactic Acid Bacteria: A Review. Food and Nutrition Sciences. $5: 1765-1775$.

Savadogo, A., C.A.T. Outtara, I.H.N. Bassole, and A.S. Traore. 2006. Bacteriocins and Lactic Acid Bacteria- a mini review. African Journal Biotechnol 5 (9): 678683.

Sriwidowati. 2003. Efektivitas Bakteri Asam Laktat Pada Pembuatan Produk Fermentasi Berbahan Baku Nabati.http://www.unri.ac.id/jurnal/jur nal natur/ vol5(2)/ Sri. pdf.

Winarno, F. G. dan I. E. Fernandez. 2007. Susu dan Produk Fermentasinya. Mbrio Press, Bogor. 